SHORT COMMUNICATIONS

\title{
FIRST RECORDED CASE OF FEMALE BROWN BEAR (URSUS ARCTOS: URSIDAE) WITH FIVE SECOND YEAR CUBS
}

\author{
Gleb A. Sedash", Dina S. Matiukhina, Petr L. Sonin, Ekaterina Yu. Blidchenko, Victor B. Storozhuk \\ National Park «Land of the Leopard», Russia \\ e-mail: gsedash@gmail.com
}

Received: 12.02.2018

\begin{abstract}
We report the first case of a super-large brown bear (Ursus arctos) litter surviving until the second year of life. In the Land of the Leopard National Park, using camera traps, we recorded a female with five cubs two times in March and in December 2017. Litters with more than four cubs are extremely rare for brown bears, and are known for newborn cubs only. We report the first documented evidence of a five-cub litter, which are very close to surviving through the first two years of their life while bear cub mortality is extremely high.
\end{abstract}

Key words: camera traps, extra-large litter, Land of the Leopard National Park, Russian Far East, Ursus arctos

Reproductive success of females and survival of their offspring are important drivers of population growth and abundance. Among many mammal species, juvenile survival is the lowest one compared to survival of other age classes. For many species of large mammals, the first year is the most vulnerable period of life because of low and highly variable survival. Juvenile survival often is the lowest and at the same time the most variable vital rate, that determines the most of the population growth rate variance (Gaillard \& Yoccoz, 2003). Hence, it is important to know not only the average, but also extreme values of juvenile survival.

On average, a breeding female brown bear ( $U r$ sus arctos Linnaeus, 1758) has 1.5-2.0 yearlings while three or four yearlings per litter are rarely observed. For example, on Kamchatka peninsula (Russia) 1.5 yearlings per litter was recorded in $2000(\mathrm{n}=346)$ and 1.8 in $2001(\mathrm{n}=441)$. Among 787 litters in total, only 16 had four cubs, and no litter of five cubs was registered (Nikanorov, 2013). A long-term study of brown bears on Kodiak Island, USA, found 2.4 cubs per litter on average (Barnes \& Van Daele, 2006). The average number of yearlings in Croatia was $1.96(n=50)$; the same study did not find any five-cub litter among 116 litters observed (Frković et al., 2001). Five and six cub litters are known for newborns only, but not for yearlings: Karelia, Russia (Danilov et al, 1979), Central Russia (Pazhetnov \& Pazhetnov, 2005), Kamchatka, Russia (Nikanorov, personal communication), Alaska, USA (Wilk et al., 1988). In addition, some cases of more than 3-cub litters result from absorption from other families as opposed to be born by the same female (Barnes \& Smith, 1993). Another case of the adoption of the first year cub is known from Kamchatka (Maksimov \& Lepskaya, 2009). Bear cub mortality is extremely high in the first two years of their life, only $15-30 \%$ of them survive (Yurgenson, 1968; Krivokhizhin \& Dunishchenko, 1987).

In this short report we discuss the case of an extra-large brown bear family, which we have recorded using the camera trap method. We analysed the data from two camera trap stations on the territory of the National Park «Land of the Leopard» (Primorsky Krai, Russia) as a part of Far Eastern leopard (Panthera pardus orientalis Schlegel, 1857) and Amur tiger (Panthera tigris altaica Temminck, 1844) monitoring programme. The camera traps (Reconyx PC900 HyperFire Professional High Output Covert IR) were placed on tree trunks along an animal trail running along the ridge crest. The first station was at an altitude of $630 \mathrm{~m}$ a.s.1. in the secondary oak (Quercus mongolica Fisch. ex Ledeb.) forest area on the watershed of the tributaries of the River Barabashevka $\left(43.17953^{\circ} \mathrm{N}\right.$, $\left.131.19389^{\circ} \mathrm{E}\right)$. The second station was at an altitude of $641 \mathrm{~m}$ a.s.1. in the mixed fir (Picea sp.) - larch (Larix sp.) - birch (Betula sp.) forest area on the watershed in the headwaters of the River Granitnaya $\left(43.49782^{\circ} \mathrm{N}, 131.28049^{\circ} \mathrm{E}\right)$. The distance between the two points, at which the litter was photographed was $22 \mathrm{~km}$.

The first time, pictures of a female brown bear with five cubs were taken on 24 March 2017 
in the northwest section of the national park near the River Barabashevka close to the international border with Heilongjiang Province of China (Fig. 1). All five cubs were older than one year. As the pictures were taken in March, i.e. 1-2 months after brown bears give birth in our study area (Bromley, 1965), newborn cubs would have been noticeably smaller.

In the second time, pictures of same brown bear litter were taken on 06 December 2017 near Granitnaya River (Fig. 2).

All of the five cubs were still together with the female. According to our knowledge, this is the first case of registration of a brown bear litter with five cubs all of whom survived through the first year of their life. Moreover, we have a strong reason to suppose that all of the five cubs can survive and the litter will not split until the spring of 2018.

Although brown bear females sometimes adopt cubs from other litters, it is extremely unlikely in our area and we conclude that all five cubs belong to the same litter. Brown bear females adopting cubs from other litters are known from areas with high density of bears due to large amounts of nutrious food. For example, during seasonal concentrations of bears on salmon rivers, brown bear females and their cubs frequently contact with other litters (Erickson \& Miller, 1963; Barnes Jr. \& Smith, 1993). In this situation, brown bear females, first, encounter cubs from other litters, and second, have food resources to feed adopted cubs in addition to their own cubs (Kodiak Bear Fact Sheet, 2008). In our study area, the number of fish in salmon rivers is low; other abundant sources of food are absent. The brown bear abundance is low compared to the maximum densities known for this species (Pikunov \& Seryodkin, 2002), making encounters with other litters unlikely.

This case represents the first evidence of an extra-large brown bear litter surviving till the second year of their life and, with high variosity, will be surviving the third year. Compared to an average number of yearlings in a litter, this litter was 2.53.0 times larger, highlighting the high variability and reproductive potential of brown bear females.

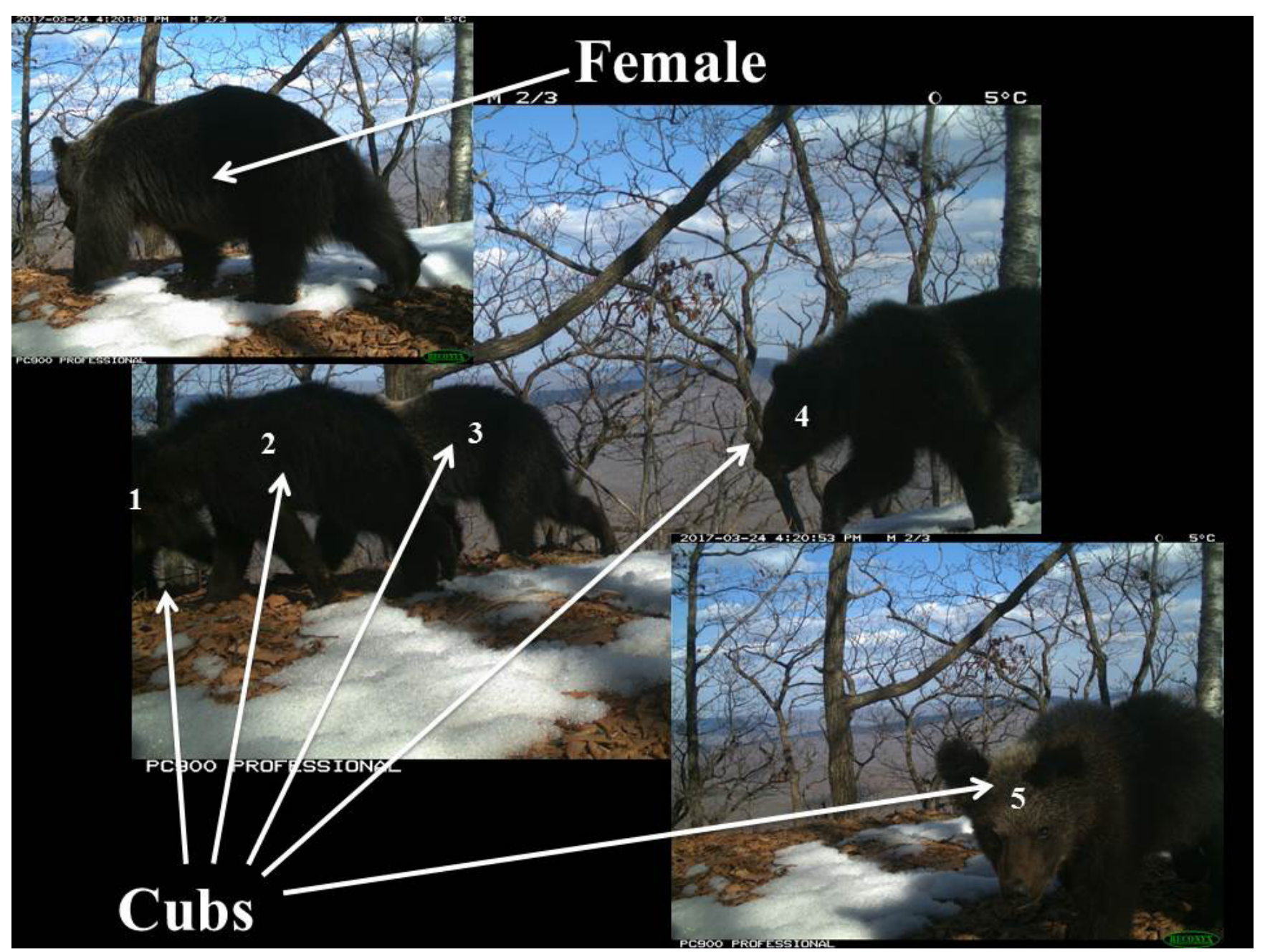

Fig. 1. Five second year cubs captured by a camera trap near the River Barabashevka in the National Park «Land of Leopard» on 24 March 2017. 


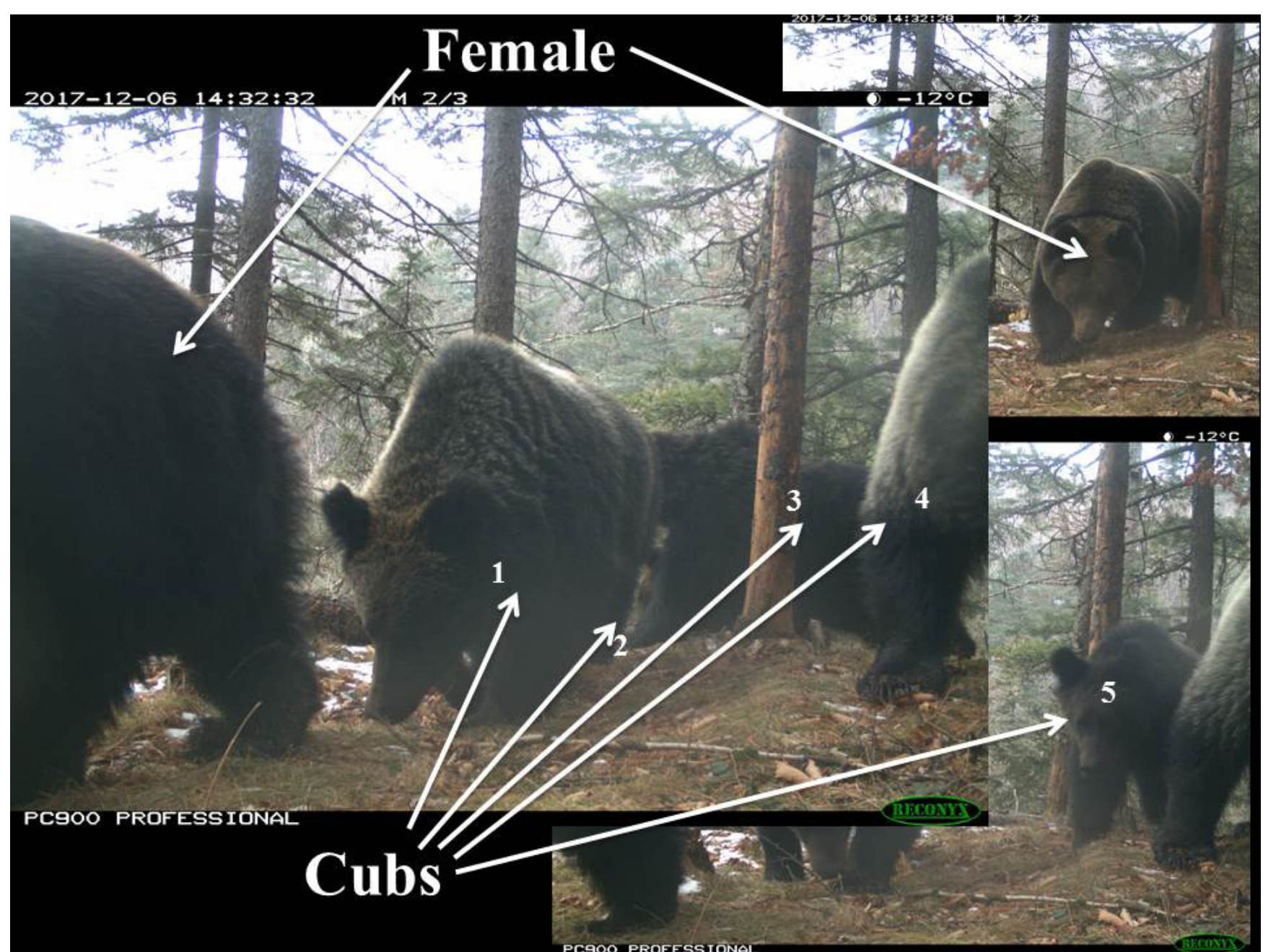

Fig. 2. Five second year cubs, which are very close to the third year, captured by camera trap near the River Granitnaya in the National Park «Land of Leopard» on 06 December 2017.

The camera trap method is a modern, useful, non-invasive method of researching with big potential that allows solving various objectives in different protected areas. This litter was registered by the developed matrix of the camera trap stations installed on the territory of the national park. The data from the camera traps used for the researching of big cats allow us to make important observations about the biology of other species as well. The camera trap distribution in protected areas gives us an opportunity to improve the level of the field researches on wild animals.

\section{Acknowledgments}

We thank the Wildlife Conservation Society (Russia), Eugenia Bragina for the invaluable help in writing the report, Irina Maslova, Yuri Petrunenko and Alexander Nikanorov for valuable comments

\section{References}

Barnes Jr.V., Smith R. 1993. Cub adoption by brown bears (Ursus arctos middendorffi) on Kodiak Island. The Canadian Field-Naturalist 107: 365-367.
Barnes V.G., Van Daele L.J. 2006. Productivity of female brown bears on Kodiak Island, Alaska. Job completion report for Challenge Cost Share Project. Kodiak, Alaska, U.S.: Alaska Kodiak National Wildlife Refuge.

Bromley G.F. 1965. Bears of the south part of the Russian Far East. Moscow: Nauka. 125 p. [In Russian]

Danilov P.L., Rusakov O.S., Tumanov I.D. 1979. Carnivores of the North-West of the USSR. Leningrad: Nauka. 164 p. [In Russian]

Erickson A.W., Miller L.H. 1963. Cub adoption in the brown bear. Journal of Mammalogy 44(4): 584-585

Frković A., Huber D., Kusak J. 2001. Brown bear litter sizes in Croatia. Ursus 12: 103-105.

Gaillard J.M., Yoccoz N.G. 2003. Temporal variation in survival of mammals: a case of environmental canalization? Ecology 84(12): 3294-3306. DOI: 10.1890/02-0409

Kodiak Bear Fact Sheet. 2008. Alaska Department of Fish and Game, Division of Wildlife Conservation. Retrieved 2008-10-27.

Krivokhizhin A.I., Dunishchenko Yu.M. 1987. Using of brown bear resources in Siberia and the Far East. In: The ecology of bears. Novosibirsk: Nauka. P. 51-56. [In Russian]

Maksimov V.V., Lepskaya E.V. 2009. Cub adoption by a bear in the South Kamchatka wildlife sanctuary in 2009. In: Conservation of the biodiversity of Kamchatka and 
adjacent seas. Petropavlovsk-Kamchatsky: Kamchatpress. P. 294-296. [In Russian]

Nikanorov A.P. 2013. New data about fertility and age structure of Kamchatka Bears. In: Conservation of biodiversity of Kamchatka and adjacent seas. PetropavlovskKamchatsky: Kamchatpress. P. 97-99. [In Russian]

Pazhetnov V.A., Pazhetnov S.V. 2005. Female brown bear with six cubs. International Bear News 14(2): 17.

Pikunov D.G., Seryodkin I.V. 2002. Current state of populations of himalayan and brown bears in the Far East of Russia and the problem of their conservation. In: Collection reports of the II International Meeting on the
Bear in the framework of the CIC. Moscow: Rosokhotrybolovsoyuz. P. 92-97. [In Russian]

Seryodkin I.V. 2006. Brown bear of Sikhote-Alin: ecology, behavior, protection and economic use. The author's dissertation abstract on competition of a scientific degree of the candidate of biological sciences. Vladivostok. 18 p. [In Russian]

Yurgenson P.B. 1968. Hunting animals and birds. Moscow; Lesnaya Promyshlennost. P. 100-109. [In Russian]

Wilk R.J., Solberg J.W., Berns V.D., Sellers R.A. 1988. Brown Bear (Ursus arctos) with six young. The Canadian Field-Naturalist 102: 541-543.

\title{
ПЕРВЫЙ ЗАРЕГИСТРИРОВАНЫЙ СЛУЧАЙ ОБНАРУЖЕНИЯ САМКИ БУРОГО МЕДВЕДЯ (URSUS ARCTOS: URSIDAE) С ПЯТЬЮ МЕДВЕЖАТАМИ-ВТОРОГОДКАМИ
}

\author{
Г. А. Седаш", Д. С. Матюхина, П. Л. Сонин, Е. Ю. Блидченко, В. Б. Сторожук \\ Наииональный парк «Земля леопарда», Россия \\ *e-mail:gsedash@gmail.com
}

\begin{abstract}
Мы сообщаем о первом случае, когда все медвежата из сверхкрупного выводка бурого медведя (Ursus arctos) пережили первый год жизни. В марте и декабре 2017 г., в национальном парке «Земля леопарда», при помощи фотоловушек, нами была зарегистрирована бурая медведица с пятью медвежатами. Выводки, состоящие более чем из четырех детенышей, крайне редко встречаются в дикой природе и известны лишь для медвежат-сеголеток. Мы сообщаем о первом случае регистрации выводка, состоящего из пяти медвежат, практически переживших первые два года жизни, когда смертность молодых медведей максимально высока.
\end{abstract}

Ключевые слова: Ursus arctos, Дальний Восток России, национальный парк «Земля леопарда», сверхкрупный выводок, фотоловушки 